\title{
Szakácsi Dr. Csorba József (1789-1858) megyeikórház-alapító és akadémikus
}

\author{
Vértes László dr.
}

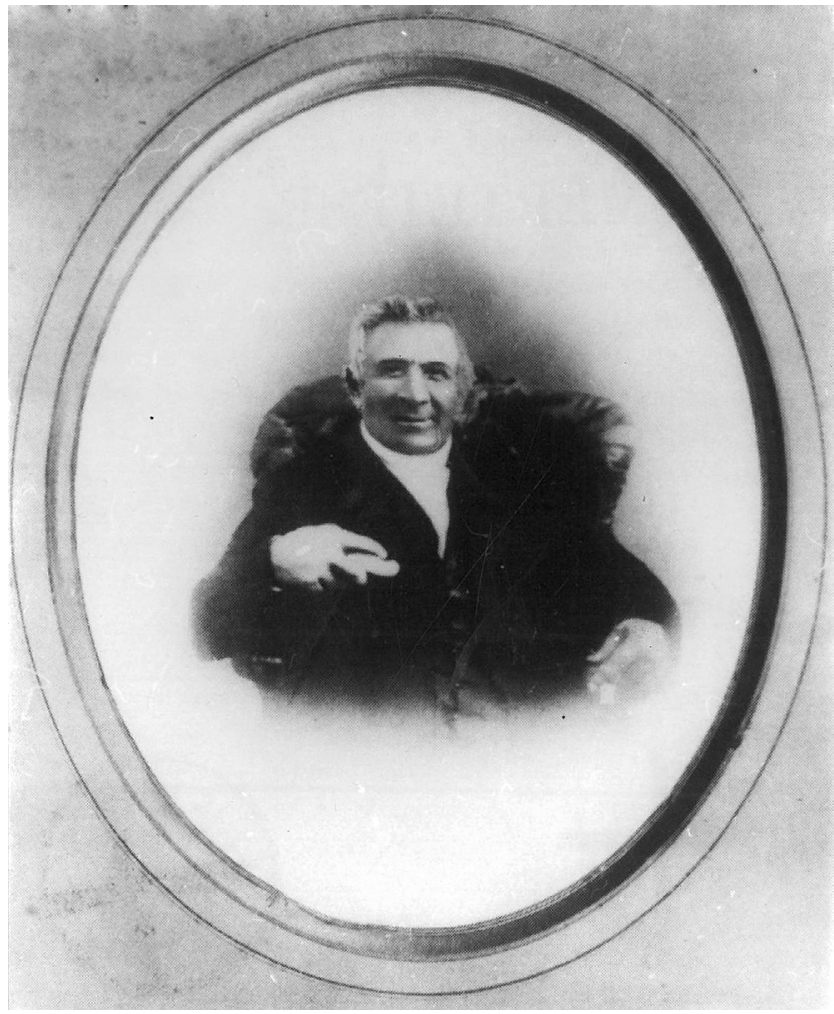

1. ábra | Korabeli fénykép Csorba Józsefről

Csorba József a magyar orvostudomány jelentős alkotója. Nagyszőllősön (Ugocsa megye) (jelenleg Vinohradiv - Nagyszőlősi járás Ukrajnában) 1789. január 11 -én született [1]. „Szegény szülőktől születtem - írja önéletrajzában -, kik noha betüt nem ismertek, mégis mind engem, mind testvéreimet iskolába járatni és maguktól megvonva is illendően nevelni el nem múlatták." Elemi iskoláit a nagyszőllősi református iskolában, majd Máramarosszigeten és Sárospatakon végezte, később a debreceni kollégiumba került. Hónapokon át nevelő volt Sárospatakon Majthényi főispán fia mellett („1000 váltó forint évi díjazással”), hogy tanulmányaira pénzt szerezzen.

Tanulmányai végén, 1811 őszén beiratkozott a pesti egyetem orvosi karára. 1817-ben orvostudorrá avatták, majd megyei föorvossá nevezték ki Somogyban, ahol 1848-ig múködött.

Kreativitása föképpen Somogy vármegyéhez kötötte. Kaposvárott 1846-ban kórházat alapított. Visszatérően szorgalmazta a nagyobb befogadóképességú megyei kórház építését. Erre irányuló figyelmét már az 1831. évi kolerajárvány felkeltette, de az öt év múlva megismétlödött, és a csaknem 2000, váratlan halálozást okozó 1836-os járvány olyan rémületet keltett, hogy az óvatos alispán is elérkezettnek látta az időt arra, hogy a vármegye határozatot hozzon megyei központi kórház építésére. A járvány utáni novemberi megyegyúlésen a fóorvosi beszámoló utolsó mondatára sokan odafigyeltek: „Újból ismétlem, a börtönkórházi tapasztalataimra is hivatkozva, hogy a vármegyei kórház megépítése az adófizetők számára sürgető kötelezettség!” Czindery alispán ezt még megtoldotta az elmebetegek, a bujakórosok, a súlyos sérültek igényeivel, amikor felkérte a közgyúlést, hozzon határozatot a vármegye kórházának közadakozásból történő felépítésére. A határozat azonnal megszületett, ső́t az adakozás is megindult. A tervező és helykereső tevékenység Csorba József főorvosra maradt, aki sógorával először az építészt kereste fel Pécsett, majd a tervvázlat birtokában gyorsan megvásárolta azt a két jobbágytelket, amely a főorvosi háztól keletre, a domb legmagasabb pontján, a Fő utcától a Meggyes kertekig húzódott, $\mathrm{s}$ az építész véleménye szerint elegendő az utcafronttal párhuzamosan, előkert mögött felépítendő emeletes kórház elhelyezésére. Csorba József foóorvos abban a reményben, hogy a kórház két éven belül elkészül, szerzett maga mellé fiatal, jól képzett, korábbi katonaorvost, Dr. Vagner Gábor soproni orvos személyében. A kórházi szabályzat elkészítéséhez elkérték néhány, már jól múködő kórház szabályzatát, s azt főképpen jogászok, gazdászok és Dr. Csorba József részvételével a helyi viszonyokhoz alkalmazkodva teljes körû alapszabályt dolgoztak ki, amelyet az 1846. májusi megyegyúlés elfogadott. 1846. november 2 -án a megyegyúlés határozatával megnyitották a kórház kapuit [2]. A vármegyei főorvos egyben a kórház igazgatója lett, aki nem kis meghatottsággal és büszkeséggel így emlékszik meg a felavatott kórházról, akkor a város büszkeségéről: „A város napkeleti felemelkedett részén fekszik, a jótékony- 
ságból és a szegény sorsú betegekről gondoskodásból magánosok által a megye és kormány felügyelete alatt, mint más ilyen intézetek, készült a már külsejével is feltûnő kórház... Homlokán egy táblát visel: A szenvedó emberiségnek, találtak benne minden vallás és nemzeti különbség nélkül helyet a betegek." Az élet furcsaságai közé tartozik, hogy a kórház avatótáblájára Dr. Csorba József neve nem került fel, holott ő volt, aki a legtöbbet tette a kórház létrehozásának érdekében [3-5].

Magyary-Kossa Gyula, az egyik legnevesebb orvostörténészünk megdöbbentő sorokat közölt Csorba Józsefről [6]: „.. az alispán, ez a vármegyei úr, valószínúleg egyéb érdekből kifogyva, így förmedt rá a vármegye főfizikusára: 'Hallgasson, maga szolga!' Ez a goromba hang kínosan hatott a megyegyúlésre, mert dédapám (ezt Nagy Emil dédunoka írta) országszerte híres orvos volt, de ő maga nem jött zavarba, hanem karjait keresztbe fonva mellén, alázatosságot tettető hangon így felelt: 'Nagyságod talán nem szolgálja a vármegyét?' - 'Igen, de én becsületért szolgálom a vármegyét, maga pedig pénzért' - válaszolt gőgösen az alispán, aminek az volt a háttere, hogy abban az időben a vármegyei hivatalok viselői nem kaptak fizetést, mert hisz birtokos urak voltak, birtokuk jövedelméból éltek, ellenben a megyei fóorvos fizetésből élt. A fófizikus erre a válaszra alázatos hangon ezt felelte: 'Mindenki azért szolgál, ami neki nincs... Nekem pénzem nincs!' Ez a zseniális finomságú, de azért igen goromba válasz nagy hírre tett szert a vármegyében. A fófizikust mindazonáltal igen bántotta, hogy őt szolgának nevezhették, s ezért sürgősen megvett egy szép birtokot a Marcali mellett fekvő Szakácsi faluban, s befogatván négyes fogatával, azonnal Bécsbe ment és meghozta a nemesi kutyabőrt 'Szakácsi' prédikátummal. Azután már, mint birtokos nemest, nem nevezhették szolgának a megyegyúlésen, ha pénzszerző orvosi foglalkozását le is nézték az urak."

1848-ban Budapestre költözött és ettől kezdve az írásoknak élt. 1832. augusztus 9-én a Magyar Tudományos Akadémia levelező tagjai közé választotta.

Írt a Tudományos Gyüjteményben, az Orvosi Tárban, a Gazdasági Tudósitásokban, az Akadémiai Értesitésekben, a Pesti Naplóban, a Magyar Néplapban és a Magyar Sajtóban. A koleráról is maradtak kéziratai.

Elsőként foglalkozott Somogy néprajzával; orvosi ismeretterjesztő munkássága jelentős. Disszertációja a visszerek tágulataival, elsősorban az aranyérrel foglalkozott. A proktológia magyarországi hőskorának egyik legelső magyar szerző által írt, igaz, latin nyelvű munkája (Pest, 1817). Csorba József az akadémiai levelezői tagságot az 1829-ben megjelent „Hygiastika vagyis orvosi oktatás, mit kell tenni... míg orvos érkezik" magyar nyelvű könyve alapján nyerte el. Ennek már alcíméből kiderül, hogy nem „tudományos”, hanem a nép felvilágosítására szolgáló mű. Akkoriban az akadémiai tagsághoz, gróf Széchenyi István elképzelése szerint, a magyar nyelv múvelésére volt szükség. Ezért kezdetben nem a tudományos érdem játszott szerepet a taggá választásban, ha- nem az a tény, hogy az illeto magyar nyelven lett „esmeretes" író. Hiába írt tehát Lenhossék Mihály többkötetes tudományos élettankönyvet, nem lett sosem akadémikus, mert e múve nem magyar, hanem latin nyelven jelent meg. Ez persze nem von le semmit Csorba József tudományos teljesítményének az értékéből, hiszen további munkáival is bizonyította kivételes képességét: „Észrevételek az éghajlatnak és más természeti okoknak befolyásáról az emberre” (Pest, 1833); „A magyarországi pokolvar, annak természete, okai, óvó- és gyógymódjai”, amely dolgozatával a Tudós Társaság (Akadémia) által meghirdetett pályázaton 2. díjat nyert (Buda, 1837); „Észrevételek az álladalmi egészség rendezéséről hazánkban” (Pécs, 1848); „Somogy vármegye ismertetése" (Pest, 1857).

1858. november 23-án, Pesten halt meg. 2016-ban jelent meg kötet a budapesti, Kálvin téri kriptákról [7]. Itt olvasható, hogy „A kriptában fekvő halottak közül nyolc személy sírhelye védett. Köztük Csorba József dr. orvos, az MTA tagja. „Utolsó lakbelye: Pest, Belváros, Magyar utca 27." A halotti anyakönyvben olvasható: „A betemetés ideje: november 26. A halál oka: gyomorbaj. Orvosa: Dr. Heinrich. Egyéb: Somogy megye volt föorvosa Patczkó Jozefa asszony férje, a holttest a pesti református egyház sírboltjába tétetett..." További értékes információk Csorba József életéról több idevonatkozó munkában megtalálhatók [8-14].

\section{Köszönetnyilvánítás}

A szerző e helyen is köszöni Csányi Nikolettnek, Faragó Fanninak, Braun Benjaminnak és Szabó Gergelynek értékes segítségüket.

\section{Irodalom}

[1] Hortobágyi Á (ed.). Lexicon of the local poets, writers and art ists. [A helyi költők, írók és múvészek lexikona.] Somogyi $\mathrm{He}$ likon, Kaposvár, 1928; p. 38. [Hungarian]

[2] Bodosi M. (ed.) Honorary Volume of County Hospital of Somogy in Kaposvár (1846-1996). [Somogy megye Kaposvári Kórházának Jubileumi Évkönyve (1846-1996).] Kaposvár, 1996; pp. 1, 2, 41. [Hungarian]

[3] Kopa J. (ed.) 160 years of Teaching Hospital of Mór Kaposi. [A Kaposi Mór Oktató Kórház 160 éve.] Kaposvár, 2006; p. 18. [Hungarian]

[4] Moizs M. Foundation for Mór Kaposi Hospital. [Kaposi Mór Megyei Kórházáért Alapítvány.] Kaposvár, 2014; p. 9. [Hungarian]

[5] Szabó Gyné, Takácsné Kamarell A. Health care in the Kaposvár Hospital between 1846 and 2005. [Az ápolás krónikája a kaposvári kórházban 1846-tól 2005-ig.] Kaposvár, 2006; pp. 16, 17, 20, 21. [Hungarian]

[6] Magyary-Kossa Gy. Hungarian medical memories. Dissertations from Hungarian Medical History. IV. [Magyar orvosi emlékek. Értekezések a magyar orvostörténelem köréből. IV.] A Magyar Orvosi Könyvkiadó Társulat Könyvtára, CLXVIII. kötet. Budapest, 1940; 623. cikkely. [Hungarian]

[7] Kő A, Susa É. (eds.) The secrets of the crypts of Kálvin square. [A Kálvin kripta titkai.] Kortárs Kiadó, Budapest, 2014. [Hungarian] 
[8] Kátai G. Remembrance of József Csorba MD. [Dr. Csorba József emlékezete.] Orv Hetil. 1859; 7. szám. [Hungarian]

[9] Szinnyei J. Life and works of Hungarian writers. Volume II [Magyar írók élete és munkái. II. kötet.] Budapest, 1893; 430. hasáb. [Hungarian]

[10] Högyes E. Honorary Volume of the Past and Presence of the Medical Faculty of the Hungarian Royal University in Budapest. [Emlékkönyv a Budapesti Királyi Magyar Tudományegyetem Orvosi Karának múltjáról és jelenéról.] A Magyar Orvosi Könyvkiadó Társulat Könyvtára. 74. kötet. Budapest, 1896; pp. 97, 231. [Hungarian]

[11] Györy T. Medical bibliography of Hungary 1472-1899. [Magyarország orvosi bibliographiája 1472-1899.] A Magyar Orvosi Könyvkiadó Társulat Könyvtára, 83. kötet. Budapest, 1900; pp. 31, 81, 109, 146. [Hungarian]
[12] Fekete Gné. Members of the Hungarian Academy of Sciences 1825-1973. [A Magyar Tudományos Akadémia tagjai 18251973.] Magyar Tudományos Akadémia Könyvtára, Budapest, 1975; p. 49. [Hungarian]

[13] Bodosi M, Frankl J. József Csorba MD (1789-1858). In: Bodosi M, Frankl J. (eds.) Excellent physicians in Somogy county (1819th centuries). [Csorba József dr. (1789-1858). In: Bodosi M, Frankl J. (szerk.) Somogy megye jeles orvosai (18-19. század).] Somogy Megyei Levéltár, Kaposvár, 1982; pp. 18-21. [Hungarian]

[14] Vértes L. József, Szakácsi Csorba MD, academician (17891858). In: Vincze J. (ed.) Memory of Hungarian physicians, 32. [Szakácsi Dr. Csorba József akadémikus (1789-1858). In: Vincze J. (szerk.) Emlékezünk orvosainkra 32.] NDP Kiadó, Budapest, 2016; pp. 69-80. [Hungarian]

\section{Ellen Notbohm-Veronica Zysk} EZEREGY NAGYSZERRUU ÖTLET AUTIZMUSSSAL ÉLŐ VAGY ASPERGER-SZINDRÓMÁS GYEREKEK NEVELÉSÉHEZ ÉS TANITTÁSÁHOZ

„Ha minden iskolában és családban a könyvben szereplő ötletek kis töredékét felhasználnák, beláthatatlan lehetöségek nyilinának meg elöttünk, hogy javítsuk az autizmussal vagy Asperger-szindrómával élö gyermekek életminöségét. Ez pedig csodálatos dolog!"

A könyv számtalan azonnal alkalmazható ötletet kínál szülőknek és nevelőknek az alábbi területeken:

- szenzoros integráció: fejlesztőfeladatok a szabadban és bent,

- kommunikáció: szóhasználat, hallás, vizualitás, környezet,

- viselkedés: tipikus viselkedési formák és kezelésük,

- mindennapi élet: ötletek a mindennapi szituációkhoz, a biztonság megteremtéséhez,

- szociális létezés: barátság, játék, kooperáció, érzelmek.

Dr. Temple Grandin 